\title{
Student Perspectives Regarding the Process of Problem Based Learning at the Faculty of Medicine and Health Sciences, University Malaysia Sarawak
}

\author{
Rasidah Abd Wahab
}

\begin{abstract}
The objective of this study was to determine the year 1 and year 2 medical students' perceptions on problem based learning (PBL) in the preclinical year curriculum. The data was drawn from a survey conducted among 134 medical students. The results indicate that the students perceived PBL to stimulate their learning environment and enable them to practice teamwork and problem solving skills. More in depth research through qualitative methods should be conducted to provide further evidence on the effectiveness of PBL and suggest areas for improvement.
\end{abstract}

\section{Introduction}

Problem based learning (PBL) first started in the Faculty of Health Sciences at the McMaster University in 1969. Since then PBL has been introduced and practiced at various medical schools as well as by other courses such as dental and engineering (Barman et al., 2006; Awang and Ramly, 2008). A number of Malaysian universities including the University Malaysia Sarawak has undertaken the challenge of adopting this approach into the present medical curriculum. PBL integrates some fundamental educational principles, and has been found to be an effective and active learning method (Malik and Malik, 2001). This method has allowed students to correlate the knowledge gained in basic sciences with clinical scenarios (University Malaysia Sarawak, 2001).

\footnotetext{
${ }^{1}$ Medical Education Unit, Faculty of Medicine and Health Sciences, University Malaysia Sarawak

Corresponding Author:

Rasidah Abd Wahab, Coordinator,

Medical Education Unit,

Faculty of Medicine and Health Sciences, University Malaysia Sarawak,

Lot. 77, Section 22

K.T.L.D. Jalan Tun Ahmad Zaidi Adruce,

93150 Kuching, Sarawak, Malaysia

Email: awrasida@fmhs.unimas.my
}

The Faculty of Medicine and Health Sciences, University Malaysia Sarawak was one of the public higher education institutions in Malaysia that offers a medical programme with integrated PBL, community-oriented learning, early clinical exposure, and a student-centered teaching/ learning approach. PBLs are introduced during the first two years of the medical programme (Medical Handbook 2009/2010 session).

\section{Need for the study}

The Faculty of Medicine and Health Sciences has implemented the PBL method into the preclinical year curriculum. Therefore a study was conducted among preclinical year students to explore students' perception on PBL in the preclinical year curriculum. Student views are vital in determining whether PBL has enhanced students' problem solving skills and teamwork skills, and whether PBLs have stimulated a conducive learning environment.

\section{Objectives}

The present study aims to determine year 1 and year 2 medical students' perceptions regarding problem based learning in the preclinical year curriculum.

\section{Methodology}

The present study was conducted among year 1 and year 2 students and questionnaires were completed by 134 randomly selected 
students. The students recruited for this study have been exposed to and attended more than four PBL sessions. The questionnaire was designed to gather student's response on three aspects of PBL exercises namely; stimulated learning environment (6 items), teamwork skills ( 3 items) and problem solving skills (2 items). The students rated the items based on a five point Likert scale (namely strongly agree $(S A)$, agree $(A)$, neutral $(N)$, disagree (DA) and strongly disagree (SDA). Data was analyzed using SPSS version 17.

\section{Results}

From the 134 medical students' who participated in the study, $37.3 \%$ were male and $62.7 \%$ were female. The distribution by race shows that about $44 \%$ students are Malays; $63 \%$ are Chinese and the remaining $8.7 \%$ are either Indian or other ethnicity. The students' response to the questionnaire is summarized in Table 1. The students have indicated positive reactions towards PBL. More than $60 \%$ of the students perceived that PBL stimulated their learning environment, while many perceived that PBLs enabled them to practice teamwork and problem solving skills.

\section{Conclusion}

These results suggest that PBL help students enhance their self development skills besides stimulating the student learning environment. More in depth study should be done qualitatively so that more evidence on the effectiveness of PBL as a teaching/learning method can be gathered and further used to improve PBLs.

Table 1: Student's Response to the Questionnaire (n=134)

\begin{tabular}{|c|c|c|c|c|}
\hline \multirow{2}{*}{\multicolumn{2}{|c|}{ Items }} & \multicolumn{3}{|c|}{ Percentage of student's response } \\
\hline & & SA $/ A$ & $\mathbf{N}$ & DA/SDA \\
\hline \multicolumn{5}{|c|}{ Stimulate Learning Environment } \\
\hline 1. & PBL sessions are effective in achieving learning objectives. & 64.9 & 28.4 & 6.7 \\
\hline 2. & PBL allows in depth understanding of the topics. & 73.9 & 23.1 & 3.0 \\
\hline 3. & $\begin{array}{l}\text { PBL motivate me to study since the problems reflects real } \\
\text { scenario. }\end{array}$ & 76.1 & 20.9 & 3.0 \\
\hline 4. & $\begin{array}{l}\text { PBL enables me to identify relevant resources with the subjects } \\
\text { to be studied. }\end{array}$ & 67.9 & 26.1 & 6.0 \\
\hline 5. & PBL allows better student participation in the learning process. & 78.4 & 17.9 & 3.7 \\
\hline 6. & $\begin{array}{l}\text { PBL allows an opportunity to listen and learn to understand the } \\
\text { problem from different perspectives. }\end{array}$ & 91.0 & - & 9.0 \\
\hline \multicolumn{5}{|c|}{ Team Work Skill } \\
\hline & $\begin{array}{l}\text { PBL allows group members to actively participate in the } \\
\text { discussion. }\end{array}$ & 76.9 & 17.2 & 6.0 \\
\hline 8. & $\begin{array}{l}\text { PBL allows an opportunity for each group member to contribute } \\
\text { ideas. }\end{array}$ & 84.3 & 14.9 & 0.7 \\
\hline & $\begin{array}{l}\mathrm{PBL} \text { allows member to assist each other to understand the } \\
\text { problem. }\end{array}$ & 80.6 & 18.7 & 0.7 \\
\hline \multicolumn{5}{|c|}{ Problem Solving Skill } \\
\hline & $\begin{array}{l}\text { PBL allows me to integrate my prior knowledge to understand } \\
\text { the problem. }\end{array}$ & 72.4 & 24.6 & 3.0 \\
\hline & $\begin{array}{l}\text { PBL allows me to integrate different disciplines to understand } \\
\text { the problem. }\end{array}$ & 60.4 & 35.8 & 3.7 \\
\hline
\end{tabular}




\section{Acknowledgement}

I would like to extend my thanks to Associate Professor $\mathrm{Dr}$ Nan Omar for reviewing the paper, and to Kamini Devi and her group members for their help in gathering the data from both year 1 and year 2 students of Medicine the Programme, University Malaysia Sarawak.

\section{References}

Awang, H., \& Ramly, I. (2008) Creative thinking skill approach through problem-based learning: pedagogy and practice in the engineering classroom. International Journal of Human and Social Sciences, 3, 1, pp. 18-23.
Barman, A., Jaafar, R., \& Ismail, N.M. (2006) Problem-based learning as perceived by dental students in University Sains Malaysia. Malaysian Journal of Medical Sciences, 13, 1, pp. 63-67.

Handbook on Introduction to PBL Curriculum and its Implementation in Faculty of Medicine and Health Sciences, Universiti Malaysia Sarawak, $3^{\text {rd }}$ Edition, January 2001.

Malik, A.S \& Malik, R.H. (2001) Introduction to Problem Based Learning (PBL) curriculum and its implementation in Faculty of Medicine and Health Sciences, University Malaysia Sarawak. Malaysian Journal of Peadiatric and Child Health, 13, pp. 54-70.

Medical Handbook 2009/2010 session, Faculty of Medicine and Health Sciences, University Malaysia Sarawak. 